\title{
Desiccation versus Re-Flooding: Heavy Metals Mobilization-Part 1
}

\author{
Sama Sameer Al-Maarofi ${ }^{1}$, Abdul Zahra Abdul Rasul Alhello ${ }^{2}$, Nadia Al-Mudaffar Fawzi ${ }^{2}$, \\ Ali Abdul Zahra Douabul ${ }^{2}$, Hamid Talib Al-Saad ${ }^{2}$ \\ ${ }^{1}$ Department of Biology, University of Waterloo, Waterloo, Canada; ${ }^{2}$ Department of Marine Environmental Chemistry, Marine Sci- \\ ence Centre, University of Basra, Basra, Iraq. \\ Email: adouabul@mscbasra.org, adouabul@live.com,sdouabul@yahoo.com
}

Received June $16^{\text {th }}, 2013$; revised July $21^{\text {st }}, 2013$; accepted August $1^{\text {st }}, 2013$

Copyright (C) 2013 Sama Sameer Al-Maarofi et al. This is an open access article distributed under the Creative Commons Attribution License, which permits unrestricted use, distribution, and reproduction in any medium, provided the original work is properly cited.

\begin{abstract}
From the restoration point of view, heavy metals distribution and seasonal variation were studied in the re-flooded marshes of the Mesopotamia, southern Iraq. As part of the ecological recovery assessment of these newly inundated marshes, it is important to investigate the extend impact of 13 years of desiccation after five years of inundation on the heavy metals mobilization from the marshland downstream into the Shatt Al-Arab River and examine whether these marshlands retain their role of acting as sink of metals. The result shows significant differences between the re-flooded marshes versus the reference marsh, which indicates that desiccation caused changes in environmental variables and divided the one homogeneous system of the Mesopotamia into separated systems. In addition, the special distribution of heavy metals shows that Al-Hawizeh and Al-Hammar marshlands were efficient for metals reduction, especially for Ni, while the Central marshland has the major contribution as source to metals. As a conclusion, the recovery potential of three marshlands is strongly controlled by the hydrological status of the marshland and the degree of the desiccation impact. The environmental status of the semidried marshes, Al-Souda north and Um Al-Niaaj, as well as the completely Abu Zarag dried marsh is exhibiting a more positive recovery degree than the other monitored marshes in the Mesopotamia in comparison to the reference marsh.
\end{abstract}

Keywords: Desiccation; Heavy Metals; Mesopotamian Marshlands; Re-Flooding; Restoration

\section{Introduction}

The recovery assessment of the re-flooded Mesopotamian marshlands has been studied intensively to report on their current ecological status comparing to their historical condition [1-4]. Mesopotamian marshlands used to be a freshwater-homogenized ecosystem [5]. In the mid of 1970, Iraq faced the intensive construction of dams in Turkey that led to reduce the annual water share of the Mesopotamia water resources, the Tigris and the Euphrates Rivers. During the Iran-Iraq war (1981-1988), the east part of the Mesopotamia (Al-Hawizeh marshland) suffered from several military activities like bombing, burning the vegetation cover, and constructing embankments for military transportation [6]. In 1993, a decision was made to dry up the marshlands and convert most of them in to an agriculture fields. From 1993 to 2002, only $10 \%$ of the marshland were preserved, $60 \%$ were become desert, and $30 \%$ were used for agriculture [7].
In natural system, marshes system can act as a sink of chemicals either through bio-concentration or sedimentation [8]. The Mesopotamian marshlands known for centuries as sink to chemicals [9]. During the water shortage period until the desiccation, the drying process led to accumulating huge amount of pollutants and salts [1] due to the way of letting the marshlands to dry [4]. After re-flooding, understanding the ecological and hydrological behavior of the inundated area becomes a key factor to figure out the possibilities and duration of restoring these areas. As part of the recovery assessment program initiated between the Iraqi universities and both University of Waterloo and Canadian International Development Agency, intensive ecological and hydrological surveys were carried between 2005 and 2008. The major objective of the program is to investigate the recovery potential of the newly re-flooded marshes. Different ecological and hydrological studies that carried out after the inundation period indicate the massive impact of de- 
siccation and water shortage on the Mesopotamian marshlands' restoration progress $[1,3,4]$.

Heavy metals are existing in the aquatic system as part of the food web; their existence is normally in an adequate amount unless they are part of pollution [10]. Heavy metals such as iron, iodine, copper, manganese, zinc, cobalt, molybdenum, selenium, and nickel are essential for normal body functions. In the Mesopotamian marshlands, heavy metals are introduced either in soluble or in particulate forms through various sources including agricultural discharge and urban runoff [9]. Heavy metals can be double-edged sword; they may exert beneficial and harmful effects on plant, animal and human life depending on their concentrations, toxicity, and ability to accumulate in aquatic ecosystems [11]. Also heavy metals can decrease the growth rates of aquatic organisms and impair their reproduction [12]. In addition, acute or chronic toxicity environment can impact the numbers and diversity of aquatic species, altering their community structure and function [12,13]. Bio-accumulation of these substances in the food chain can put terrestrial consumers, including humans, at risk [13].

There are several physical and chemical parameters including water temperature (WT) salinity, $\mathrm{pH}$, dissolved oxygen (DO), and organic matter that play significant roles in remobilizing and solubility of these elements and their uptake by aquatic biota [14,15]. For example, high WT and low DO environment enhance the toxicity of copper [16]. Low pH $(<7.0)$ can diminish the mobilization of copper, especially when dissolved organic matter concentration is low [11]. Conversely, high $\mathrm{pH}(>8.0)$ increases the formation of toxic copper hydroxide [16]. Alkalinity controls metals toxicity by forming insoluble carbonates [17]. On the other hand, salinity can decrease the toxicity of cadmium [16].

This work is focusing on understanding the desiccation role on re-mobilizing cobalt $(\mathrm{Co})$, copper $(\mathrm{Cu})$, iron, $(\mathrm{Fe})$, manganese $(\mathrm{Mn})$, nickel $(\mathrm{Ni})$ in the water and the sediment of the newly re-flooded marshes. $\mathrm{Co}, \mathrm{Cr}, \mathrm{Fe}$ and $\mathrm{Mn}$ were chosen as they are part of the essential require trace elements for living organisms, while Ni was chosen as its importance as indicator to petroleum pollution. The main objectives of this study are to investigate the seasonal and special variation of these metals among marshes that has different hydrological history; identify the main physical and chemical parameters that control heavy metals distribution; and examine whether the newly marshland system is acting as a sink or source of heavy metals?

\section{Materials and Methods}

\subsection{Study Site Description}

Total of thirteen sampling stations were selected includ- ing twelve distributed in the three major marshlands of the Mesopotamia as two stations in the Al-Hammar marshland, two stations in the Central marshland, and eight stations in the Al-Hawizeh marshland; and last station were chosen close to the main water outlet of the marshlands (Figure 1; Table 1). The selected stations represent different hydrological history since the desiccation in 1993. Al-Udhaim marsh represents the ever-wet part of the Al-Hawizeh marshlands that has a direct and continues water input from Iran during desiccation period. In contrast to the rest of the selected stations those are partially or completely dried during the desiccation period. Furthermore, the selected stations were varied according to their vegetation cover. The field observation suggests differences in the hydrological and habitat structure of the selected marshes (Table 1). The differences in the ecological structure of each group will be used to determine the differences in the desiccation impact on each selected marsh.

\subsection{Field Work}

Seasonal water and sediment samples were collected twice, once in winter 2008 (February) and once again in summer 2008 (June). Physical and chemical parameters including WT, salinity, DO, and $\mathrm{pH}$ were measured using the WTW Multi-meter model 350i. Water samples were collected using a Van Dorn sampler. $1 \mathrm{~L}$ was transported in to plastic bottles for major ions determination, while $20 \mathrm{~L}$ were transport in to plastic gallons for metals determination. Sediment samples were collected using a Van Veen grab sampler then wrapped in plastic bag. Bothe water and sediment samples were transported to the laboratory in cool boxes.

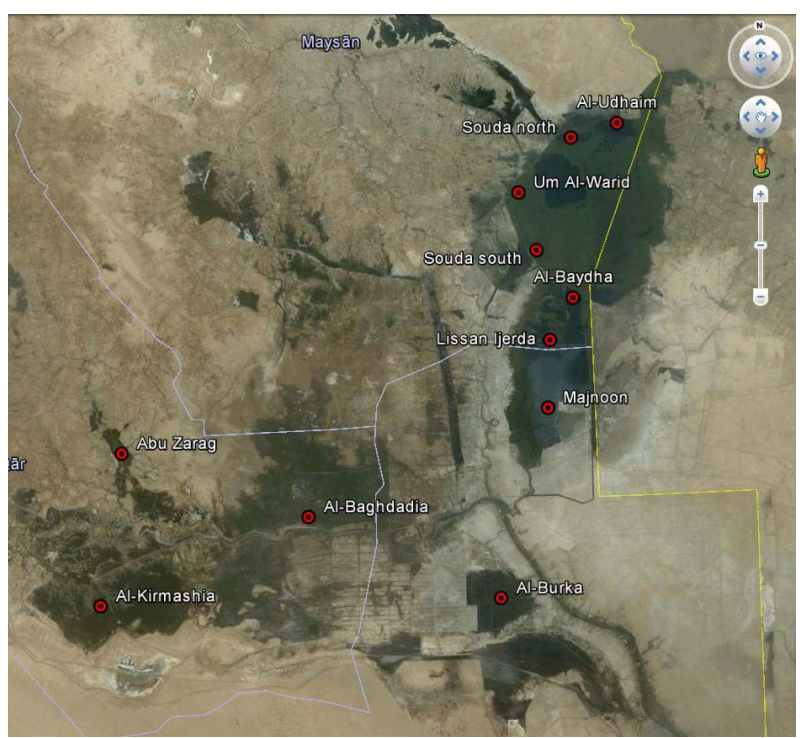

Figure 1. Satellite image shows the three main marshlands of the Mesopotamia including the sampling marshes. 
Table 1. General description and classification of the studied stations in the Mesopotamian marshlands during the study period.

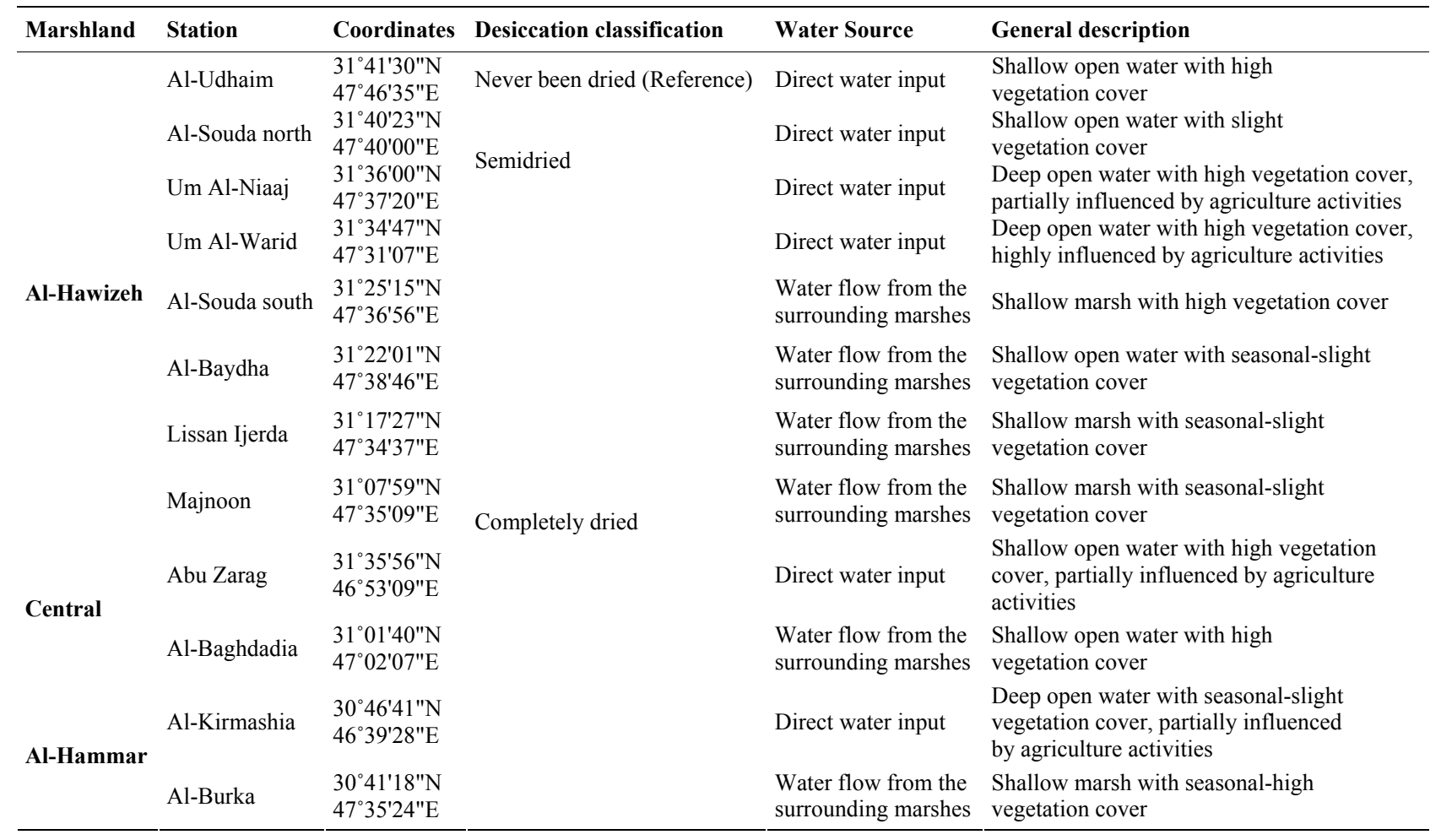

\subsection{Laboratory Analysis}

Major ions concentrations including calcium (Ca), magnesium $(\mathrm{Mg})$, chloride $(\mathrm{Cl})$, and were determined by titration method, while sulfate $\left(\mathrm{SO}_{4}\right)$ determined by photometric method according to the standard procedures described in [18]. Heavy metals concentrations in water were determined according to the method described by [19]. Sediment samples were freeze-dried, ground finely in agate mortar and sieved through $62 \mathrm{um}$ stainless-steel sieve. Metals concentrations in the sediment samples were determined using Atomic Absorption Spectrophotometer technique according to the procedure described by [20].

To check the possible loss of metals during the pre-concentration and/or digestion procedures, quality control samples for trace metals in water and sediments supplied by the US Environmental Protection Agency (USEPA) were process and analyzed. The results of triplicate analysis agreed with the giving values to within $5 \%$. The recovery rates of heavy metals in the standard reference material were around 91\% - 97\%. However, results were not corrected for recovery rates of heavy metals. Reagent blanks were also employed to detect potential contamination during the digestion and analytical procedure. Mean grain size analysis was carried out using the standard sieving and pipet techniques [21], were as the total organic carbon content of the sediment was deter- mined by the method described by [22].

\subsection{Data Analysis}

Seasonal variations of metals were tested using twosample t-test among different sample sites at the level of $P \leq 0.05$. Pearson correlation coefficient analysis was used to evaluate correlations among heavy metals in the sediment and water and general aquatic quality parameters. Principal Component Analysis (PCA) was conducted to investigate associations of different sample sites and assess the major sources of metals in studied locations. The monitored stations were grouped in to four categories: the reference (Al-Udhaim marsh) represents the stable and undisturbed marsh, riverine marshes include the marshes that located close to the water inputs, marsh proper include the marshes that located far from the water inputs, and the outlet that indicate the status out of the marshlands. Average concentrations of heavy metals of each category were plotted to examine the role of marshlands in their mobilization.

\section{Results and Discussion}

\subsection{Seasonal Variation}

Generally, the mean concentrations of all the tested metals in the water are higher in the summer rather than winter. However, in the sediment, $\mathrm{Ni}$ and Co concentra- 
tions were higher in winter rather than summer in contrast to the rest of the metals. $\mathrm{Mn}, \mathrm{Cu}$, and Co concentrations in the water show significant seasonal variations, while all the metals concentrations in the sediment except for $\mathrm{Fe}$ show significant seasonal variations (Figure 2, Table 2). The behaviour of heavy metals seasonal
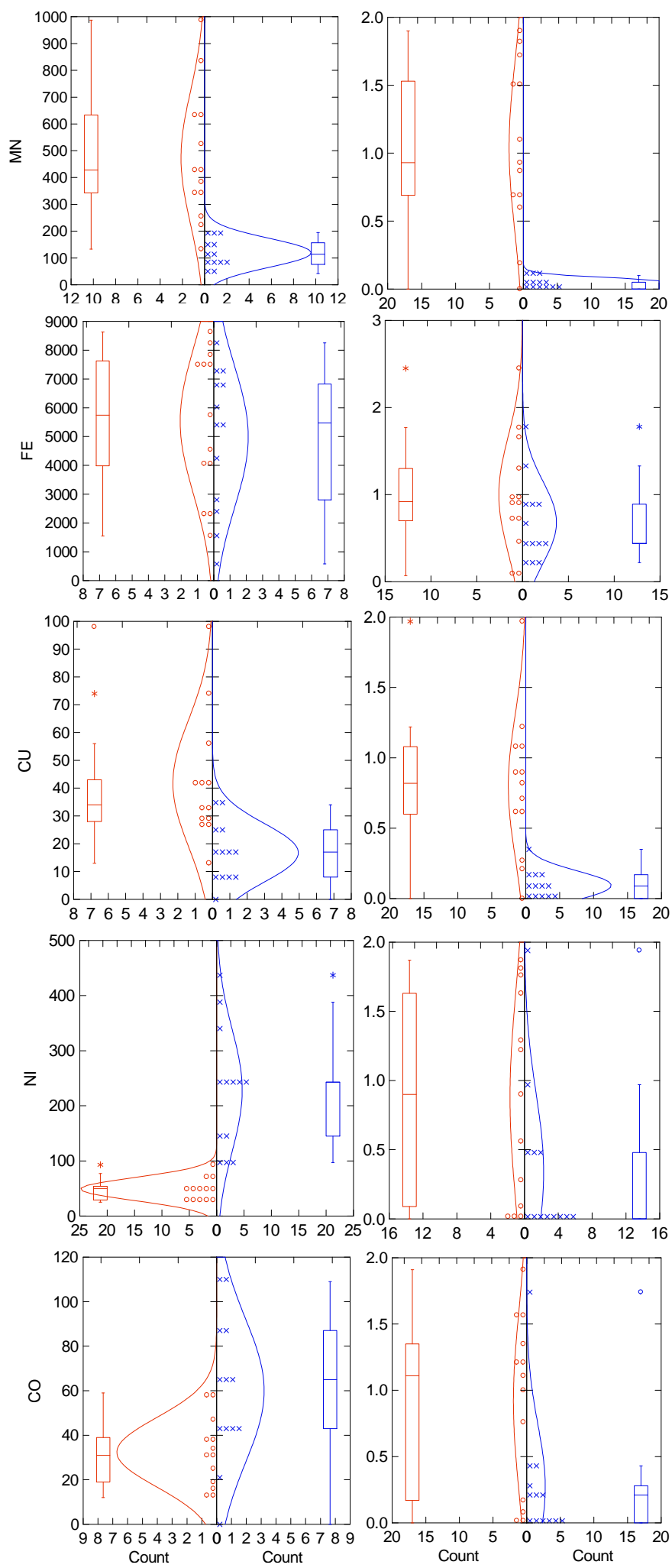

SEASON

Figure 2. Seasonal variation of heavy metals concentrations in the Mesopotamian marshlands. 
Table 2. Two-sample t-test on heavy metals grouped by seasons. $S=$ Summer, $W=$ Winter, $M=M e a n$.

\begin{tabular}{|c|c|c|c|c|c|c|c|c|c|c|c|}
\hline & & \multicolumn{5}{|c|}{ Sediment $(\mu \mathrm{g} / \mathrm{g})$} & \multicolumn{5}{|c|}{ Water $(\mu \mathrm{g} / \mathrm{l})$} \\
\hline & & $\mathbf{M}$ & SD & $\mathbf{t}$ & df & $\mathbf{P}$ & $\mathbf{M}$ & SD & $\mathbf{t}$ & df & $\mathbf{P}$ \\
\hline \multirow{2}{*}{ Mn } & $\mathbf{S}$ & 474.1 & 244.6 & 5.106 & 12.1 & 0.000 & 1.0 & 0.6 & 5.927 & 13.2 & 0.000 \\
\hline & $\mathbf{W}$ & 119.3 & 54.1 & & & & 0.0 & 0.0 & & & \\
\hline \multirow{2}{*}{$\mathrm{Fe}$} & $\mathbf{S}$ & 5532.0 & 2523.7 & 24.000 & 21.5 & 0.584 & 1.0 & 0.7 & 1.405 & 24.0 & 0.174 \\
\hline & $\mathbf{W}$ & 4989.5 & 2454.1 & & & & 0.7 & 0.5 & & & \\
\hline \multirow{2}{*}{$\mathrm{Cu}$} & $\mathbf{S}$ & 41.8 & 22.7 & 3.599 & 13.0 & 0.002 & 0.8 & 0.5 & 4.929 & 16.9 & 0.000 \\
\hline & $\mathbf{W}$ & 16.8 & 10.5 & & & & 0.1 & 0.1 & & & \\
\hline \multirow{2}{*}{$\mathbf{N i}$} & $\mathbf{S}$ & 48.9 & 20.9 & -5.703 & 22.4 & 0.000 & 0.9 & 0.8 & 2.063 & 12.8 & 0.051 \\
\hline & $\mathbf{W}$ & 227.8 & 111.1 & & & & 0.3 & 0.6 & & & \\
\hline \multirow{2}{*}{ Co } & $\mathbf{S}$ & 32.4 & 15.4 & -2.773 & 21.7 & 0.013 & 0.9 & 0.7 & 2.884 & 17.2 & 0.009 \\
\hline & W & 60.0 & 32.4 & & & & 0.3 & 0.5 & & & \\
\hline
\end{tabular}

variation and distribution in the Mesopotamian marshlands reflect the interaction functions between substrate sediment composition, water chemistry, and water discharge $[23,24]$. Low water discharge during the summer season can be the most important factors control the seasonal variation of metals in the water, especially in the marshes are located close to the water inputs $[25,26]$. In summer when evaporation rate is high the dilution rate of metals in water decreased and thus their concentrations increased significantly than winter [11]. Biogeochemical activities are the most significant factors responsible for the seasonal variation of metals in the sediments [27]. Microorganisms increased their activities late spring, which mostly responsible of increasing metals and organic matter concentrations in the sediment [12]. Among the tested metals, Fe average concentrations in both water and sediment were higher than the other metals in the three marshlands, especially in Al-Hawizeh marshland; while $\mathrm{Cu}$ average concentrations were lower than the other metals in the three marshlands, especially in Al-Hawizeh and Central marshlands.

\subsection{Special Variation}

The distributions of heavy metals in the water and the sediment were varied among the marshlands (Figure 3). For instant, in Al-Hawizeh marshland $\mathrm{Ni}$ average concentration in the north part of the marshland, especially in Um Al-Warid marsh, was high. As the water flows downstream, Ni average concentrations are gradually decreased to completely consume as they appears in both Lissan Ijerda and Majnoon marshes. In contrast, the low average concentrations of $\mathrm{Fe}$ and Co recorded in the upper part of the Al-Hawizeh were gradually increased as the water pass forward. In Al-Hammar marshland, the high average concentrations of $\mathrm{Ni}, \mathrm{Cu}$, and $\mathrm{Fe}$ in the Al-Kirmashia marsh are decrease as the water pass towered Al-Burka marsh, while Co and Mn average concentrations were increased. In the Central marshlands, it appears that the average concentrations of all the tested metals are increasing as the water flows from Abu Zarag marsh towered Al-Baghdadia marsh. In the sediment, metals concentrations were also varied significantly (Figure 3). In general, Fe average concentrations were higher in the marshes downstream than marshes close to the water inputs, while Co average concentrations were higher in the marshes close to the water inputs rather than marshes downstream. $\mathrm{Mn}, \mathrm{Cu}$ and $\mathrm{Ni}$ average concentration were varied among the three marshlands (Figure 3). In Al-Hawizeh marshland, Mn average concentrations were high in the marshes downstream, when $\mathrm{Cu}$ and $\mathrm{Ni}$ average concentrations were high in the marshes close to the water inputs. In Central marshland, $\mathrm{Ni}$ average concentrations were high in the marshes downstream, when $\mathrm{Mn}$ and $\mathrm{Cu}$ average concentrations were high in the marshes close to the water inputs. In the Al-Hammar marshland, $\mathrm{Cu}$ and $\mathrm{Ni}$ average concentrations were high in the marshes downstream, when Mn average concentrations were high in the marshes close to the water inputs.

\subsection{Metals Correlations with Water Quality Parameters}

The Pearson correlation coefficient (Table 3) for water variables and heavy metals shows positive correlations between $\mathrm{Mn}, \mathrm{Cu}$ and WT as well as between each other. $\mathrm{pH}$ were negatively correlated to $\mathrm{Mn}, \mathrm{Cu}$, and $\mathrm{Ni}$, while alkalinity was negatively correlated to $\mathrm{Mn}$ and $\mathrm{Cu}$. In the sediment, Ni and Co were positively correlated. WT 

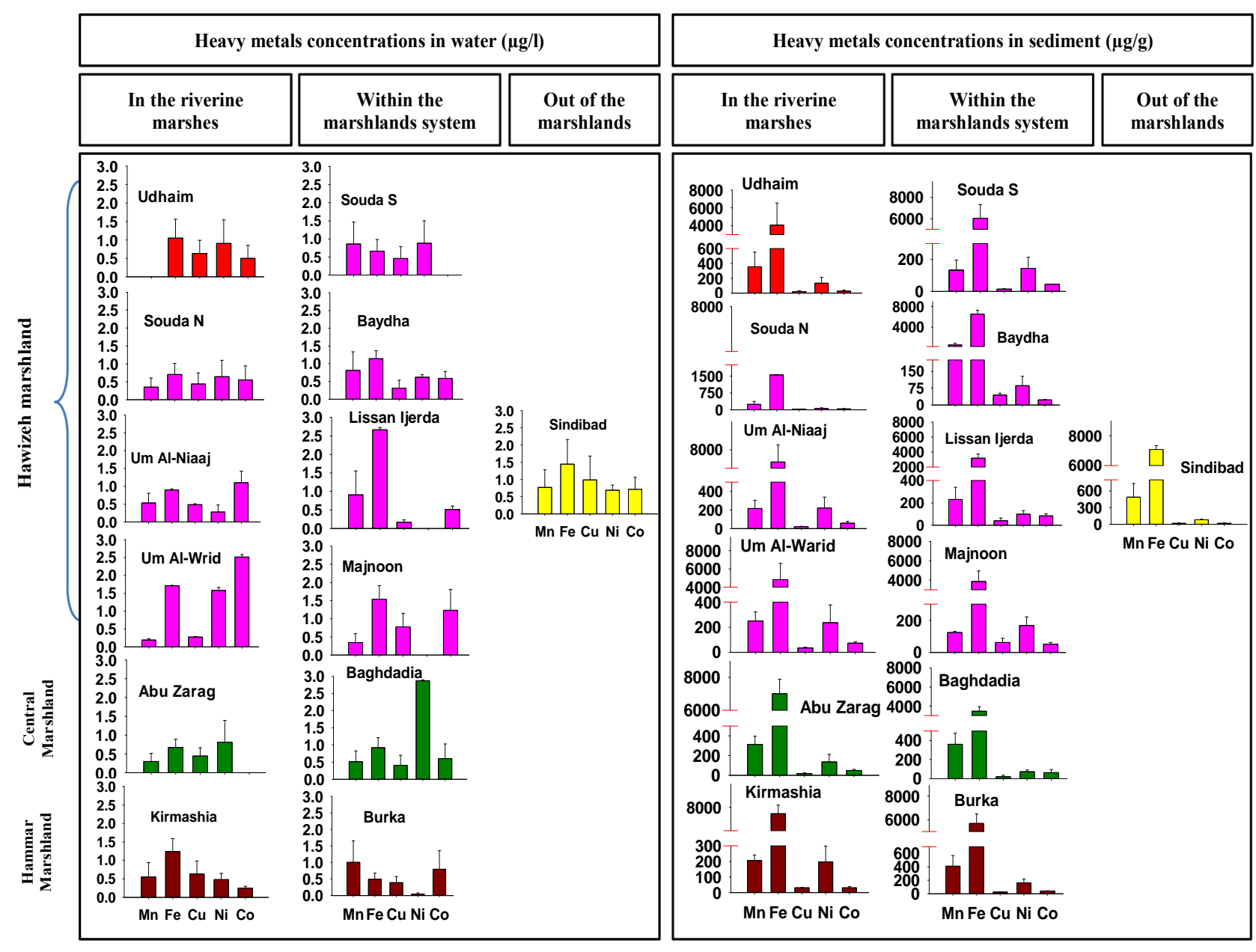

Figure 3. Spatial distribution of heavy metals in the Mesopotamian marshlands.

positively correlated to $\mathrm{Mn}$ and $\mathrm{Co}$, while it is negatively correlated to $\mathrm{Ni}$ and $\mathrm{Co} . \mathrm{pH}$ is positively correlated to $\mathrm{Mn}$ and negatively correlated to $\mathrm{Ni}$. Alkalinity is positively correlated to $\mathrm{Ni}$ and negatively correlated to $\mathrm{Mn}$ and $\mathrm{Cu}$. It is interesting that salinity shows no correlations to heavy metals either in water or in sediment. In addition, only $\mathrm{Mn}$ in water and sediments were positively correlated. The principal component analysis (PCA) shows how different the marshes were in the ordination (Figure 4). The PCA also shows that the three main marshlands, Al-Hawizeh, Central and Al-Hammar, were different from each other; and also there were differences between the marshes within the same marshland. Although there were a close similarly between the semidried marshes, Al-Souda north and Um Al-Niaaj and the reference marsh, but the completely dried marshes were significantly different. Also the PCA designate the ecological structure of each marsh. It is shown that salinity and major ion are the most water quality variables that classify A-Hammar marshland than Al-Hawizeh and the Central marshlands, which are mostly classified according to their sediment structure, $\mathrm{pH}$ and alkalinity. The
PCA provides some indications for association of heavy metals and environmental parameters among the monitored marshes [17]. Water of the reference marsh was significantly characterized by it high $\mathrm{pH}$ well oxygenated, while sediment has high amount of organic matter, which indicate a healthy productive system. In contrast, the completely dried marshes were significantly different than the reference marsh. As shown in Figure 5, the desiccated marshes' water has high salinity and major ions concentration and their sediment were heavily loaded with metals [25]. However, the ecological structure of Abu Zarag, Souda north, and Um Al-Niaaj marshes in comparison to the reference marsh (Al-Udhaim) is relatively correlated, which is a positive indication that these marshes are successfully recovering.

\subsection{Marshlands Role in Metals Mobilization}

Figure 5 shows the metals average concentrations in water and sediment in order to describe their mobilizations within the studies locations. Comparing to the reference site, metals average concentration in the three 
Table 3. Matrix of Pearson correlation coefficient for water and sediment variables and heavy metals for the selected stations in the Mesopotamia marshlands.

\begin{tabular}{|c|c|c|c|c|c|c|c|c|c|c|c|c|c|c|c|c|c|c|c|c|}
\hline & \multicolumn{9}{|c|}{ Sediment variables } & \multicolumn{10}{|c|}{ Water variables } \\
\hline & & $\mathrm{Mn}$ & $\mathrm{Fe}$ & $\mathrm{Cu}$ & $\mathrm{Ni}$ & Co & TOC & $\%$ Sand & $\%$ Clay & $\%$ Silt & WT & $\mathrm{pH}$ & Salinity & Do & $\mathrm{Ca}$ & $\mathrm{Mg}$ & $\mathrm{Cl}$ & $\mathrm{SO} 4 \mathrm{~A}$ & Alkalinity & $\mathrm{Mn} \mathrm{Fe} \mathrm{Cu} \mathrm{Ni} \mathrm{Co}$ \\
\hline \multirow{7}{*}{ 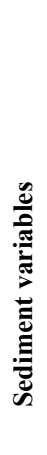 } & $\mathrm{Mn}$ & 1.0 & & & & & & & & & & & & & & & & & & \\
\hline & $\mathrm{Fe}$ & 0.3 & 1.0 & & & & & & & & & & & & & & & & & \\
\hline & $\mathrm{Cu}$ & 0.3 & -0.1 & 1.0 & & & & & & & & & & & & & & & & \\
\hline & $\mathrm{Ni}$ & -0.6 & 0.1 & -0.3 & 1.0 & & & & & & & & & & & & & & & \\
\hline & Co & -0.4 & -0.3 & -0.3 & 0.5 & 1.0 & & & & & & & & & & & & & & \\
\hline & TOC & 0.1 & 0.0 & -0.2 & -0.1 & -0.3 & 1.0 & & & & & & & & & & & & & \\
\hline & $\%$ Sand & 0.1 & 0.1 & -0.3 & 0.1 & -0.2 & 0.1 & 1.0 & & & & & & & & & & & & \\
\hline \multirow{16}{*}{ 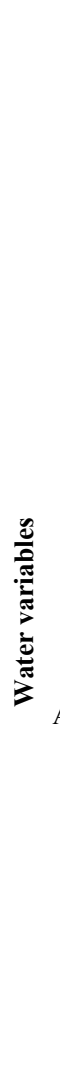 } & $\%$ Clay & 0.1 & 0.2 & 0.0 & 0.1 & -0.2 & 0.2 & 0.0 & 1.0 & & & & & & & & & & & \\
\hline & $\%$ Silt & -0.1 & -0.2 & 0.1 & -0.1 & 0.2 & -0.1 & -0.3 & -0.9 & 1.0 & & & & & & & & & & \\
\hline & WT & 0.7 & 0.1 & 0.6 & -0.7 & -0.4 & 0.0 & 0.0 & 0.0 & 0.0 & 1.0 & & & & & & & & & \\
\hline & $\mathrm{pH}$ & -0.6 & -0.2 & -0.2 & 0.5 & 0.4 & 0.0 & 0.0 & -0.1 & 0.1 & -0.6 & 1.0 & & & & & & & & \\
\hline & Salinity & 0.1 & 0.2 & -0.1 & 0.1 & -0.1 & -0.3 & 0.3 & 0.2 & -0.4 & -0.2 & -0.1 & 1.0 & & & & & & & \\
\hline & Do & -0.2 & -0.2 & -0.1 & 0.3 & 0.1 & 0.1 & 0.1 & 0.0 & 0.1 & -0.3 & 0.3 & -0.2 & 1.0 & & & & & & \\
\hline & $\mathrm{Ca}$ & -0.4 & 0.0 & -0.4 & 0.5 & 0.3 & -0.5 & 0.2 & 0.0 & -0.2 & -0.7 & 0.3 & 0.7 & -0.1 & 1.0 & & & & & \\
\hline & $\mathrm{Mg}$ & -0.1 & 0.1 & -0.1 & 0.2 & 0.0 & -0.5 & 0.1 & 0.1 & -0.2 & -0.3 & 0.0 & 0.9 & -0.1 & 0.8 & 1.0 & & & & \\
\hline & $\mathrm{Cl}$ & -0.1 & 0.1 & -0.2 & 0.2 & 0.0 & -0.4 & 0.2 & 0.2 & -0.4 & -0.3 & 0.0 & 0.9 & 0.0 & 0.8 & 0.9 & 1.0 & & & \\
\hline & $\mathrm{SO} 4$ & -0.1 & 0.1 & -0.2 & 0.2 & 0.0 & -0.4 & 0.2 & 0.2 & -0.3 & -0.5 & 0.1 & 0.9 & -0.1 & 0.9 & 0.9 & 0.9 & 1.0 & & \\
\hline & Alkalinity & -0.7 & -0.2 & -0.5 & 0.8 & 0.4 & 0.2 & 0.1 & 0.0 & 0.0 & -0.7 & 0.4 & 0.1 & 0.5 & 0.4 & 0.2 & 0.2 & 0.2 & 1.0 & \\
\hline & $\mathrm{Mn}$ & 0.7 & 0.2 & 0.4 & -0.5 & -0.3 & -0.1 & 0.0 & 0.1 & -0.2 & 0.8 & -0.5 & 0.0 & -0.4 & -0.3 & 0.0 & -0.1 & -0.1 & -0.6 & 1.0 \\
\hline & $\mathrm{Fe}$ & 0.3 & 0.2 & 0.3 & -0.2 & 0.1 & -0.2 & -0.1 & -0.3 & 0.3 & 0.3 & -0.2 & -0.1 & 0.2 & -0.3 & -0.2 & 0.0 & -0.3 & -0.3 & $0.2 \mathbf{1 . 0}$ \\
\hline & $\mathrm{Cu}$ & 0.6 & 0.2 & 0.4 & -0.5 & -0.4 & 0.0 & 0.1 & 0.0 & 0.0 & 0.7 & -0.6 & -0.1 & -0.1 & -0.5 & -0.2 & -0.1 & -0.3 & -0.5 & $\begin{array}{lll}\mathbf{0 . 5} & 0.4 & \mathbf{1 . 0}\end{array}$ \\
\hline & $\mathrm{Ni}$ & 0.3 & 0.1 & -0.1 & -0.4 & -0.1 & 0.3 & -0.1 & -0.1 & 0.2 & 0.4 & -0.5 & 0.1 & -0.3 & -0.3 & -0.1 & -0.1 & -0.1 & -0.4 & $0.1 \quad 0.10 .3 \quad \mathbf{1 . 0}$ \\
\hline & Co & 0.4 & 0.0 & 0.5 & -0.2 & -0.1 & -0.2 & 0.0 & 0.2 & -0.1 & 0.5 & -0.3 & -0.2 & 0.0 & -0.4 & -0.2 & -0.1 & -0.3 & -0.4 & $\begin{array}{lllll}0.3 & 0.3 & 0.4 & 0.2 & 1.0\end{array}$ \\
\hline
\end{tabular}

groups gives indicate that the Mesopotamian marshlands are source of $\mathrm{Co}, \mathrm{Cu}, \mathrm{Fe}, \mathrm{Mn}$, and $\mathrm{Ni}$ as their average concentrations in the outlet is higher than their average concentrations in the marshes close to the water inputs.

Metals average concentration in the sediment shows different pattern of mobilization (Figure 5). Mn average concentration in the marshes close to the water input and within the system is lower than the reference site. $\mathrm{Fe}, \mathrm{Cu}$, and Co average concentrations in the marshes close to the water inputs and within the system are higher than the reference site. $\mathrm{Ni}$ average concentrations in the marshes close to the water input are higher than the reference site, while its average concentrations in the system was lower than the reference site. Metals average concentrations in completely dried marshes are higher than the reference marsh [16], which is mostly correlated to the desiccation sequences. The main sources of heavy metals in wetlands are through river inputs and sediment 


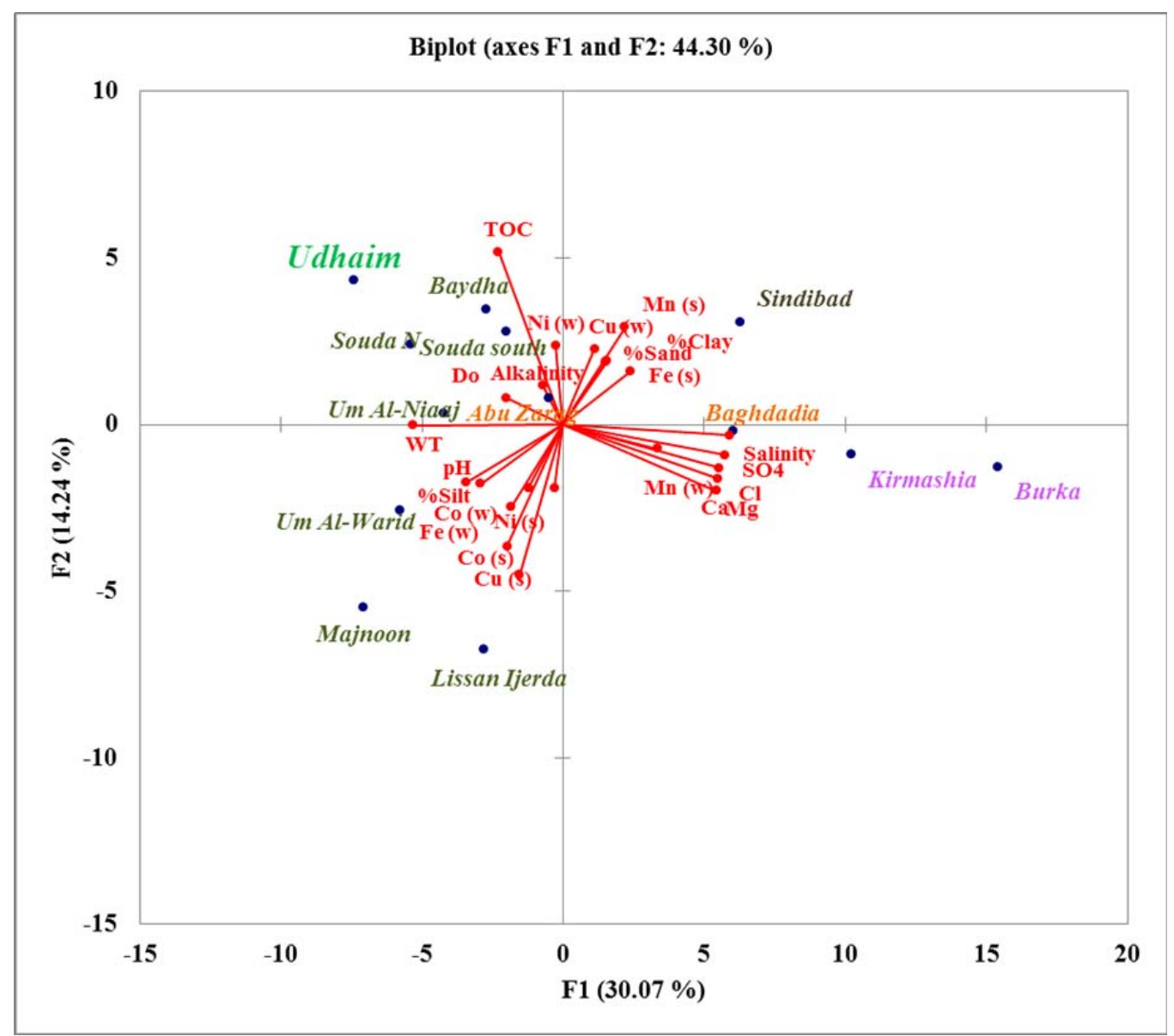

Figure 4. PCA of heavy metals and environmental parameters in water and sediment of 13 marshes in the Mesopotamia.

[24,28]. Historically, when the Mesopotamian marshlands were naturally active, they act as sink to metals [9]. No significant non-point or point pollution sources of metals were indicated in to the marshlands before desiccation [9]. Generally, the spatial distribution of heavy metals concentrations in water and sediment in wetlands show a significant trend [29]. In case of the Mesopotamian marshlands the drying process led to accumulate layers of metals as water left to dry gradually. After re-flooding, the water flushes the top layer of sediment and led to re-dissolve the metals from the sediment into the water. Despite the mechanism of metals interaction between the water and the sediment, wetlands generally acting as source of metals since the metals concentrations out of the marshlands system are higher than their concentrations within the system $[8,26]$. Among the three marshlands of the Mesopotamia, Al-Hawizeh reacts healthier than Central marshland and Al-Hammar marshland due to its ability to act as sink of Ni. Al-Hammar marshland comes in the second place since it has the ability to reduce the amount of $\mathrm{Ni}, \mathrm{Cu}$, and $\mathrm{Fe}$, while Central marshland shows no ability to decrease any of the metals instead it was the major source of these metals.

\section{Conclusion}

The mechanism of metals distribution and mobilization in surface water and surface sediment in re-flooded marshlands that have different hydrological history was investigated through field research. The newly re-flooded marshes of the Mesopotamia express different status of recovery in contrast to the reference marsh. Heavy metals mobilization and distribution were highly correlated to the hydrological status and desiccation degree. The marshes which were completely dried have the highest concentration of metals in both sediment and water comparing to the semidried marshes. Al-Hawizeh marshland among the Central and Al-Hammar marshlands shows a positive recovery stage in terms of acting as a sink to metals, where the Central marshland was the major source of metals into Shatt Al-Arab.

\section{Acknowledgements}

Authors are grateful to the Canadian International Development Agency (CIDA) and University of Waterloo for their motivation and support in pursuing research activities. We are also thankful to the Marine Science 


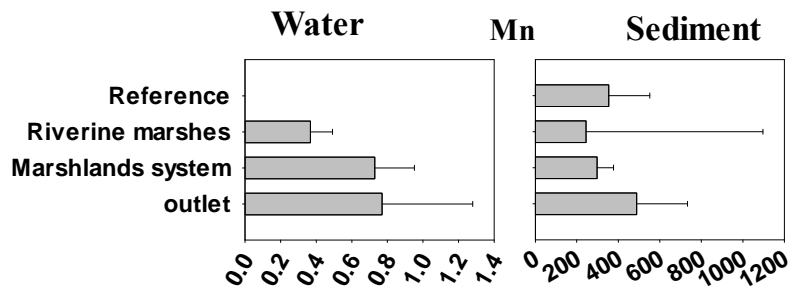

$\mathrm{Fe}$

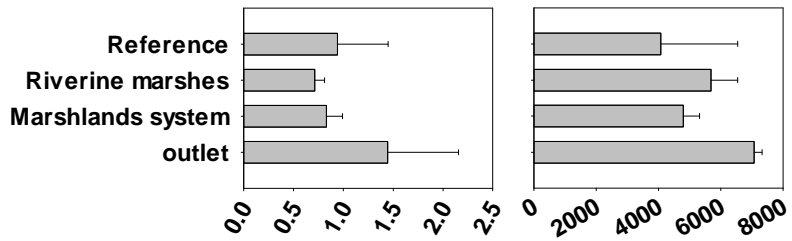

$\mathrm{Cu}$

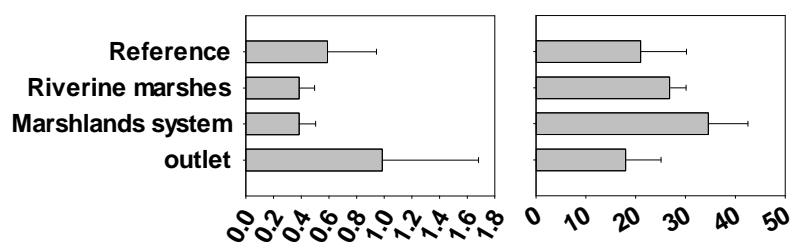

$\mathrm{Ni}$
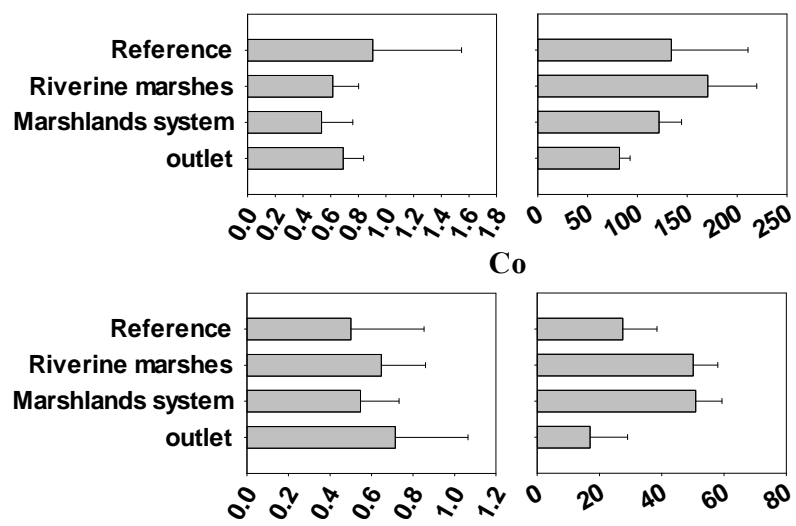

Figure 5. Comparison of the average concentrations of metals in water $(\mu \mathrm{g} / \mathrm{l})$ and sediment $(\mu \mathrm{g} / \mathrm{g})$ between reference site, marshes are close to water inputs, marshes within the marshlands system, and outlet.

Centre, University of Basra for their contribution on field work and data analysis.

\section{REFERENCES}

[1] C. J. Richardson, P. Reiss, N. A. Husain, A. J. Alwash and D. J Pool, "The Restoration Potential of the Mesopotamian Marshes of Iraq," Science, Vol. 307, No. 5713, 2005, pp. 1307-1310. doi:10.1126/science. 1105750

[2] C. J. Richardson and N. A. Husain, "Restoring the Garden of Eden: An Ecological Assessment of the Marshes of Iraq," BioScience, Vol. 56, No. 6, 2005, pp. 477-488. doi:10.1641/0006-3568(2006)56[477:RTGOEA]2.0.CO;2

[3] S. S. AlMaarofi, A. Douabul and H. Al-Saad, "Mesopotamian Marshlands: Salinization Problem," Journal of Environmental Protection, Vol. 3, No. 1, 2012, pp. 12951301. doi:10.4236/jep.2012.310147
[4] A. Douabul, N. Al-Mudhafer, A. Alhello, H. Al-Saad and S. S. Al-Maarofi, "Restoration versus Re-Flooding: Mesopotamia Marshlands," Hydrology Current Research, Vol. 3, No. 5, 2012, p. 140.

[5] J. Rzoska, "Euphrates and Tigris, the Mesopotamian Ecology and Destiny," W. Junk, The Hague, Boston, Hingham, 1980. doi:10.1007/978-94-009-9171-2

[6] S. Kubba, "The Iraqi Marshlands and the Marsh Arabs: The Ma'dan, Their Culture and the Environment," 1st Edition, Garnet Publishing, Berkshire, 2011.

[7] H. Partow, "The Mesopotamian Marshlands: Demise of an Ecosystem-Division of Early Warning and Assessment," United Nations Environment Programme, Nairobi, 2001.

[8] W. J. Mitsch and G. J. Gosselink, "Wetlands," 4th Edition, John Wiley \& Sons, Inc., Hoboken, New Jersey, 2007.

[9] N. A. Husain, "Ahwar of Iraq: Environmental Approach," 
The Marine Science Center Publisher, Basra, 1994.

[10] R. Alagarsamy and J. Zhang, "Geochemical Characterization of Major and Trace Elements in the Coastal Sediments of India. Environ," Environmental Monitoring and Assessment, Vol. 161, No. 1-4, 2010, pp. 161-176. doi:10.1007/s10661-008-0735-2

[11] C. S. Mueller, G. J. Ramelow and J. N. Beck, "Spatial and Temporal Variation of Heavy Metals in Sediment Cores from the Calcasien River/Lake Complex," Water Air Soil Pollution, Vol. 43, No. 3-4, 1989, pp. 213-230.

[12] N. Belzile, C. Yu-Wei, J. Gunn and S. Dixit, "Sediment Trace Metal Profiles in Lakes of Killarney Park, Canada: from Regional to Continental Influence," Environmental Pollution, Vol. 130, No. 2, 2004, pp. 239-248. doi:10.1016/i.envpol.2003.12.003

[13] D. M. Ongeri, J. O. Lalah, S. O. Wandiga, K. W. Schramm and B. Michalke, "Levels of Toxic Metals in Multisectoral Samples from Winam Gulf of Lake Victoria," Bulletin of Environmental Contamination and Toxicology, Vol. 82, No. 1, 2009, pp. 64-69. doi:10.1007/s00128-008-9530-6

[14] A. Kabat-Pendias and H. Pendias, "Trace Elements in Soil and Plants," CRC Press, Boca Raton, 2001.

[15] M. Canli and G. Atli, "The Relationship between Heavy Metal (Cd, Cr, Cu, Fe, Pb, Zn) Levels and the Size of Six Mediterranean Fish Species," Environmental Pollution, Vol. 121, No. 1, 2003, pp. 129-136. doi:10.1016/S0269-7491(02)00194-X

[16] H. T. Odum, "Heavy Metals in the Environment: Using Wetlands for Their Removal," 1st Edition, Lewis Publishers, CRC Press LLC., 2000.

[17] N. E. Akbulut and A. M. Tuncer, "Accumulation of Heavy Metals with Water Quality Parameters in Kizilirmak River Basin (Delice River) in Turkey," Environmental Monitoring and Assessment, Vol. 173, No. 1-4, 2011, pp. 387-395. doi:10.1007/s10661-010-1394-7

[18] APHA, "Standard Methods for the Examination of Water and Wastewater," 21st Edition, American Public Health Association, 2005.

[19] J. Riley and D. Taylor, "Chelating Resins for the Concentration of Trace Elements from the Sea Water and Their Analytical Use in Conjunction with Atomic Absorption Spectrophotometry," Analytica Chimica Acta, Vol. 40, 1968, pp. 479-489. doi:10.1016/S0003-2670(00)86764-1

[20] R. Chester and F. Voutsinou, "The Initial Assessment of Trace Metal Pollution in Costal Sediments," Marine Pol- lution Bulletin, Vol. 12, No. 3, 1981, pp. 84-91. doi:10.1016/0025-326X(81)90198-3

[21] R. L. Folk, "The Natural History of Crystalline Calcium Carbonate: Effect of Magnesium Content and Salinity," Journal of Sedimentary Petrology, Vol. 44, No. 1, 1974, pp. $40-53$.

[22] S. El-Wakeel and J. Riley, "The Determination of Organic Carbon in Marine Mud," Journal du Conseil International pour l'Exploration de la Mer, Vol. 22, No. 2, 1957, pp. 180-183.

[23] L. Birch, K. Hanselmann and R. Bachofen, "Heavy Metal Conservation in Lake Cadagno Sediments: Historical Records of Anthropogenic Emissions in a Meromictic Alpine Lake," Water Research, Vol. 30, No. 3, 1996, pp. 679-687. doi:10.1016/0043-1354(95)00231-6

[24] P. S. Harikumar and T. S. Jisha, "Distribution Pattern of Trace Metal Pollutants in the Sediments of an Urban Wetland in the Southwest Coast of India," International Journal of Engineering Science and Technology, Vol. 2, No. 5, 2010, pp. 840-850.

[25] M. A. S. Coetzee, "Water Pollution in South Africa: Its Impact on Wetland Biota," In: G. I. Cowan, Ed., Wetlands of South Africa, Department of Environmental Affairs and Tourism, Pretoria, 1995, pp. 187-290.

[26] M. Masson, G. Blanc and J. Schäfer, "Geochemical Signals and Source Contributions to Heavy Metal $(\mathrm{Cd}, \mathrm{Zn}$, $\mathrm{Pb}, \mathrm{Cu})$ Fluxes into the Gironde Estuary," Science of the Total Environment, Vol. 370, No. 1, 2006, pp. 133-146. doi:10.1016/j.scitotenv.2006.06.011

[27] M. J. Al-Haidarey, F. Hassan, A. Al-Kubaisey and A. Douabul, "The Geo-Accumulation Index of Some Heavy Metals in Al-Hawizeh Marsh, Iraq," E-Journal of Chemistry, Vol. 7, No. S1, 2010, pp. 157-162.

[28] D. Zaharescu, P. Hooda, A. Soler, J. Fernandez and C. Burghelea, "Trace Metals and Their Source in the Catchment of the High Altitude Lake Respomuso, Central Pyrenees," Science of the Total Environment, Vol. 407, No. 11, 2009, pp. 3546-3553. doi:10.1016/i.scitotenv.2009.02.026

[29] O. Perceval, Y. Couillard, B. Pinel-Alloul, E. Bonneris and P. Campbell, "Long-Term Trends in Accumulated Metals ( $\mathrm{Cd}, \mathrm{Cu}$ and $\mathrm{Zn}$ ) and Metallothionein in Bivalves from Lakes within a Smelter-Impacted Region," Science of the Total Environment, Vol. 369, No. 1-3, 2006, pp. 403-418. doi:10.1016/j.scitotenv.2006.04.019 